\title{
Plant Tissue, Cells
}

National Cancer Institute

\section{Source}

National Cancer Institute. Plant Tissue, Cells. NCI Thesaurus. Code C18945.

Tissue and cells derived from plants 